\title{
The Design of New Technologies Addressing Independence, Social Participation \&Wellness for Older People Domicile in Residential Homes
}

\author{
Joan Cahill \\ Centre for Innovative Human Systems (CIHS), School of \\ Psychology \\ Trinity College Dublin (TCD) \\ College Green, Dublin 2, Ireland \\ cahilljo@tcd.ie
}

\author{
Sean Mc Loughlin \& Delaine Blazek \\ Senior Living, Oneview Healthcare \\ Unit 1, Blackrock Business Park, Blackrock, Co. Dublin, \\ Ireland \\ smcloughlin@oneviewhealthcare.com, \\ dblazek@oneviewhealthcare.com
}

\begin{abstract}
This paper reports on human factors research concerning the development of new technology enabling older people to lead meaningful and independent lives in a residential home and/or assisted living community. A key goal of the technology is to support a vision of care where older people are socially engaged and have continuity in living experience. This research adopts a stakeholder evaluation/participatory approach to requirements elicitation and user interface design. The emphasis is on understanding the context and meaning of experience and associated technology need. Specifically, the technology is defined from the perspective of addressing and achieving key stakeholder states/benefits associated with wellbeing, successful ageing, and relationship centered care. Primarily, the focus of this paper is on reporting field research findings relating to resident need and the technology solution.
\end{abstract}

Keywords-older people, ageing, wellbeing, social participation, assistive technology, residential homes

\section{INTRODUCTION}

\section{A. Ageing}

Ageing is a normal part of life. Although certain diseases occur in old age, old age itself is not a disease. Ageing is often associated with changes and loss (i.e. changes in ability and way of life, loss of independence and loss of loved ones). Positive accounts of ageing focus on opportunities for personal growth. Psychosocial models emphasize life satisfaction, social participation, functioning, and psychological resources [1]. As evidenced in biopsychosocial models of health and well-being, medical, psychological factors and social factors impact on a person's health and well-being [2].

\section{B. Social Isolation \& Relational Autonomy}

Social isolation and loneliness is a common experience for older people [3], and can negatively impact on their mental and physical health. Autonomy is conceptualized in relation to exercising individual choice, freedom of will, and assuming responsible for one's own behavior and/or self [4]. Given that human relationships are based on mutual dependence and partnership, autonomy cannot be considered separately from the relationships within which individuals are embedded [5].

\section{Care Approaches}

Recently, there has been a move towards relationship centered care [6]. As human beings are active relational beings, nurturing positive social relationships is foundational to well-being, having a bearing on health care experiences and outcomes.

\section{Residential Care}

Historically, residential care facilities addressed societal goals (for example, freeing up hospital beds, taking burdens off families, coping with poverty amongst elderly), as opposed to addressing the needs of those domicile in them [7]. Recently, there has been a 'culture change' in residential care, with more attention to relationships, resident preferences and promoting intergenerational contact.

\section{E. Assistive Living Technologies}

New technologies are being advanced to support the needs of older people living both independently and in assisted living contexts. In parallel, technologies are being developed for other stakeholders. This includes care/nursing staff, family/informal caregivers, and healthcare providers. Such technologies support diverse functions including health and activity monitoring, care co-ordination and management, emergency alerting and education.

Many of the technologies deployed in residential care contexts are associated with observing/monitoring the resident (i.e. keeping them safe). There is less of an emphasis on promoting independence and social participation. The residential context is a home. New technologies need to support communication and connection (i.e. community dwelling) and not simply risk assessment. Arguably, a distinction can be drawn between assistive technology (i.e. supporting the resident in a community dwelling context) and surveillance technology (which has benefits for caregivers but not always residents). 


\section{METHOD}

\section{A. Overview}

This is a human factors action research study combining several qualitative research methods including ethnography (interviews and observations) and participatory design [8]. The human factors design approach is premised on the assumption that solutions for older people and other actors are interconnected. Accordingly, a stakeholder evaluation based approach is adopted [9]. Human factors research involves active and ongoing participation of end users (i.e. older people) and other key stakeholders.

The methodological approach is guided by phenomenological approaches to eliciting information about 'lived experience'. In line with interpretative Phenomenological Analysis [10], the emphasis is on understanding the context and meaning of experience, and the interactions between seniors and relevant stakeholders in their personal and professional community (i.e. family members, carers, friends, GP and specialists).

In relation to participatory design activities, the methodology draws upon person centered design approaches specifically, 'personae based design' [11]. Personae's have been advanced for older people living in different settings with different needs. This ensures that the proposed technology is cognizant of: (1) the experiences and needs of end users in different settings and situations (i.e. lifespan perspective home, assisted living community and residential homes), and (2) the specific needs of end users and other stakeholders in the residential care context.

As detailed in Table 1 below, technology development follows several iterative activities pertaining to (1) needs analysis, benefits analysis and requirements elicitation, (2) user interface design prototyping and (3) evaluation. Certain research phases are sequential (phases 1 and 2), while others are running in parallel and are iterative (phases 3, 4, 5 and 6).

Table 1: Research Phases

\begin{tabular}{|c|c|r|}
\hline $\begin{array}{c}\text { Research } \\
\text { Phase }\end{array}$ & Research Phase/Activity & $\begin{array}{r}\text { Stakeholder } \\
\text { Involvement }\end{array}$ \\
\hline 1 & Literature analysis & $\begin{array}{r}\text { Internal } \\
\text { stakeholders }\end{array}$ \\
\hline 2 & $\begin{array}{c}\text { Preliminary definition of } \\
\text { philosophy/approach, concept, } \\
\text { high level requirements and } \\
\text { associated personae } \\
\text { specification }\end{array}$ & $\begin{array}{r}\text { Internal } \\
\text { stakeholders }\end{array}$ \\
\hline 3 & $\begin{array}{c}\text { Requirements elicitation } \\
\text { (processing mapping, } \\
\text { interviews and observations } \\
\text { with end users and } \\
\text { stakeholders) }\end{array}$ & $\begin{array}{c}\text { External } \\
\text { stakeholders }\end{array}$ \\
\hline 4 & $\begin{array}{c}\text { Elaboration of concept and } \\
\text { philosophy and specification } \\
\text { of detailed requirements and } \\
\text { personae }\end{array}$ & $\begin{array}{r}\text { Internal } \\
\text { stakeholders }\end{array}$ \\
\hline 5 & $\begin{array}{c}\text { User interface design } \\
\text { prototyping }\end{array}$ & $\begin{array}{c}\text { Internal } \\
\text { stakeholders }\end{array}$ \\
\hline
\end{tabular}

\begin{tabular}{|c|c|r|}
\hline 6 & Co-design and evaluation & $\begin{array}{r}\text { Internal and } \\
\text { external } \\
\text { stakeholders }\end{array}$ \\
\hline 7 & Final specification and design & $\begin{array}{r}\text { Internal and } \\
\text { external } \\
\text { stakeholders }\end{array}$ \\
\hline
\end{tabular}

\section{B. Community of Practice}

As part of stakeholder design/evaluation activities, a 'Community of Practice' (COP) [12] has been formed comprising both internal and external stakeholders. Both internal and external stakeholders are involved in different research activities. Internal stakeholders include members of the assisted living project/research team (i.e. human factors researchers, user experience designers, developers, product owners, nurses and experts in health informatics). External stakeholder comprises two participant groups (1) end users and (2) other stakeholders. End users are split into four subgroups - comprising seniors living independently and living in residential homes, potentially living with one or more morbidities, with different levels of functional and cognitive ability, and an age range of between 60 to 90 years. Other stakeholders include three sub-groups, (a) family members, (b) formal aged care staff - (i.e. aged care nurses, care assistants and community nurses) and (c) other stakeholders (i.e. GPs, geriatricians, experts in ageing, volunteers in active ageing groups and volunteers/staff of relevant groups/societies). End users and other stakeholders are participating in research phases $3,6 \& 7$.

\section{Summary of Research to Date.}

To date, forty-seven interviews have been undertaken. This includes older people living independently, aged care nurses, family members, volunteers and experts in ageing and dementia. Observations have been undertaken in two day hospitals spanning health assessments and case management. A Version 1 prototype has been developed following the analysis of field research findings. The first phase of codesign/evaluation sessions with the stakeholder panel has been completed. Over the coming months, three further phases of co-design/evaluation will be undertaken. Moreover, additional field research will be conducted at a post-acute care community unit, and at a residential home (involving the participation of residents and nursing/care staff).

\section{KEY FINDINGS}

Successful ageing is multidimensional and includes psycho-social elements. In relation to older people, this research outlines several states to be (1) promoted (for example, quality of life, wellness, independence, social participation, identity, privacy and safety), (2) managed and/or mitigated (for example, self neglect, loss of identity, loss of privacy, loss of physical liberty, fear, communications difficulty, stress, loneliness, boredom, confusion and depression) and (3) avoided (for example, deception, objectification, infantization, and neglect). For more, please see [13]. 
Older people are not a homogeneous group and have different needs/experiences. In general, participants reflected a desire to remain independent and not become a burden on their families. Adaptation is a key feature of the ageing experience. Participants reported an increased acceptance in relation to reduced quality of life as they age (i.e. stoicism). All participants highlighted the importance of maintaining identity irrespective of changes/loss. Change and loss is accompanied with an increased need to focus on the home, and maintaining social/lifestyle routines associated with the home. All participants reported increased dependence on caregivers (formal and informal), family and friends as they age. There is much variety in social/family participation. Loneliness and boredom is a common feature of the ageing experience. Participants reported varying needs as regard social participation.

Residential care is associated with advanced illness (including Dementia) and incapacity. Care homes are conceived as places that older people transition to 'when their situation is acute' and/or they 'have no other choice'. As reported by participants, the 'world' of the care home/assistive living community is often very different to the world that the older person and their families are familiar with. There is a focus on risk prevention. Personal freedom often suffers in favor of resident safety. Consistently, it was noted that if a person is not actively involved and responsible for their own care, they can become disempowered and lose purpose. Although there been considerable improvement in relation to understanding the social needs of older people, the need for social participation and intergenerational contact is often overlooked (and/or undervalued) in residential settings. Some care homes have links into the community and place an importance on intergenerational contact (i.e. links to schools, local choirs and local library).

Many older people reported feeling overwhelmed by technology. All participants reported that if they were familiar with the technology (how it works, what it does), and if it clearly addressed their motivations (well-being, independence), then they might be more likely to accept it. Participants were concerned about their ability to use/interact with the tablet system. All participants stated that they would expect some training in relation to using the tablet.

Participants queried whether this technology might be used directly by residents in care homes. All participants indicated that the tablet solution would need to be very simple (i.e. not providing too much options/choice and/or information). It was also noted that many people in residential care have early cognitive decline and/or dementia. Accordingly, their ability to interact with tablet systems might be limited. In this way, future technology should be adaptive in relation cognitive ability.

There was a general perception that the implementation of such technology might be focused on organizational goals (i.e. about reducing costs of care and risk assessment), as opposed to being focused on resident need. All participants suggested that the technology might reflect a balance between the needs of residents and of care staff/the organization. In addition, family need might also be considered.

This technology might be useful in relation to keeping residents both active and engaged. It was noted that future technology might enable residents to maintain social connections and 'keep in touch with family and friends'. This was distinguished from 'providing companionship'. A tablet solution can afford the opportunity to make a telephone or video/Skype Call. However, it cannot replace the lived experience of 'being in a relationship' and/or 'the company of family and friends' and associated communications/supports.

Participants liked the idea that from a resident perspective, much of the technology might be happening in the background (i.e. bed sensors, sensors on windows/doors etc.). Further, the Tablet might provide simple/fast access to a small number of functions that are meaningful to seniors (as opposed to unnecessary noise).

As highlighted by participants, the advancement of assistive technology raises questions in relation to the values of society and how we design technology to promote positive values around ageing. In relation to the resident, a key goal is to promote independence, wellbeing, social participation and family involvement. As such, participants responded positively to technologies which support these values. Consistently, participants expressed concern about the use of (1) health monitoring technology, activity (i.e. blood pressure, pulse), (2) activity monitoring technology (i.e. movement sensors, bed sensors, fall sensors) and (3) security technology (i.e. door locking, GPS tracking). These technologies were perceived as raising fundamental questions in relation to resident autonomy, dignity and the protection of the personal sphere. All participants agreed that residents should be able to opt in/out of sensors. These technologies also raise questions concerning the value placed on 'in person' human contact. There was general agreement that such technologies might lead to a reduction in human contact, and that this should be avoided.

\section{PROPOSED SOLUTION}

\section{A. Overview}

The primary objective is to have a resident focus and enable relationship centered care. Accordingly, the proposed functionality is conceptualized in relation to stakeholder relationships. A suite of interrelated technologies is being advanced for seniors and other stakeholders (i.e. nurses, care assistants, admissions/administration personnel, family members, GP etc.). Specifically, the technology enables all actors to be involved in care. This includes some actors whose roles/responsibilities may not previously have been perceived as part of care delivery (for example, staff involved in preadmissions, admissions, maintenance staff and concierge).

Overall, the concept is to develop a range of self-decided services (opt in/out), based on what matters to older people, and to allow for personalization. Every older person is unique, has specific needs and different abilities. Needs assessment and customization is thus a necessary first step in relation to the implementation of the solution for individual residents. 
The resident chooses what functions are available on the tablet, and how they appear on the user interface.

The resident directly interacts with certain technology (for example, the resident tablet), while other technology is invisible (i.e. ambient sensors in the resident's room). The primary interaction will be with the resident tablet device. This tablet device may or may not cast to the resident's in room TV. Depending on the functional and cognitive ability of the resident, the resident will receive help using the tablet device (ability philosophy).

As defined in Table 2 below, the resident solution promotes: (1) Identity, (2) Wellness, (3) Independent Living, (4) Communication, (5) Social Participation/Community Engagement and (6) Self-Management.

Table 2: Resident Experience \& Technology Features

\begin{tabular}{|c|c|c|}
\hline \# & Theme & $\begin{array}{c}\text { Resident Experience \& Technology } \\
\text { Features }\end{array}$ \\
\hline 1 & $\begin{array}{l}\text { Identity, } \\
\text { Rights \& } \\
\text { Control }\end{array}$ & $\begin{array}{l}\text { Technology elicits information about who } \\
\text { the person is, what matters, preferences - } \\
\text { at different points in process timeline } \\
\text { Person is active decision maker and } \\
\text { consents to devices/sensors } \\
\text { Access all personal and health information } \\
\text { Person involved in care/decisions } \\
\text { Control over who sees what information } \\
\text { Capture/record information about medical } \\
\text { directives and power of attorney }\end{array}$ \\
\hline 2 & $\begin{array}{l}\text { Wellness } \\
\text { (biopsyc } \\
\text { hosocial) }\end{array}$ & $\begin{array}{c}\text { Wellness surveys } \\
\text { Free movement (monitoring not } \\
\text { surveillance) } \\
\text { Engagement - social participation, } \\
\text { activities } \\
\text { Relaxation/stress management } \\
\text { Sharing of wellness data with relevant } \\
\text { actors (nurse, family) } \\
\text { Access to entertainment } \\
\text { functions/information } \\
\text { Control over room settings }\end{array}$ \\
\hline 3 & $\begin{array}{l}\text { Enabling } \\
\text { Social } \\
\text { Participat } \\
\text { ion }\end{array}$ & $\begin{array}{c}\text { Buddy system } \\
\text { Social coaching re club events, residential } \\
\text { home events, events in wider community } \\
\text { Social profile - share with others } \\
\text { Focus on clubs and membership of } \\
\text { community }\end{array}$ \\
\hline 4 & $\begin{array}{c}\text { Commun } \\
\text { ications } \\
\text { with } \\
\text { Family }\end{array}$ & $\begin{array}{c}\text { Communications with Circle of care } \\
\text { Sharing photos } \\
\text { Activity updates } \\
\text { Quick access to skype } \\
\text { Notifications - new video message }\end{array}$ \\
\hline 5 & $\begin{array}{l}\text { Commun } \\
\text { ications } \\
\text { with } \\
\text { Care } \\
\text { Team }\end{array}$ & $\begin{array}{c}\text { Beyond just emergency help } \\
\text { Getting information about care team today } \\
\text { Personalized messages (video/text) } \\
\text { Making care requests } \\
\text { Profile info (who are/what matters) } \\
\text { available to care staff (prime them about } \\
\text { person and what matters) } \\
\text { Care team view recent social activity }\end{array}$ \\
\hline
\end{tabular}

\begin{tabular}{|c|c|c|}
\hline & & $\begin{array}{c}\text { Care team see surveys - how } \\
\text { feeling/sleeping }\end{array}$ \\
\hline 6 & $\begin{array}{c}\text { Taking } \\
\text { control/i } \\
\text { ndepende } \\
\text { nt living }\end{array}$ & $\begin{array}{c}\text { Access to health records and care plans } \\
\text { Meal ordering } \\
\text { Attending events } \\
\text { Concierge - order taxi, book hairdresser } \\
\text { Adjusting room settings } \\
\text { Capture/record information about medical } \\
\text { directives \& power of attorney } \\
\text { Opt in/out sensors } \\
\text { Maintaining identity } \\
\text { Control over who sees what information }\end{array}$ \\
\hline 7 & $\begin{array}{c}\text { Self- } \\
\text { Manage } \\
\text { ment }\end{array}$ & $\begin{array}{c}\text { Notifications - biomarkers } \\
\text { Education and goals } \\
\text { Access to health records and care plans } \\
\text { Communicate about how feeling } \\
\text { Coaching in relation to attending events, } \\
\text { planning activities }\end{array}$ \\
\hline
\end{tabular}

Implicit in the technology concept is the notion of resident rights in relation to dignity, privacy and choice. The proposed technology addresses all three pillars of well-being and the interrelationship therein. Specific functions promote wellness and map to the underpinning biopsychosocial model of health and well-being. The proposed technology considers models of successful ageing - supporting social participation, addressing stress, mood and engagement, providing entertainment functions and promoting self-management and purposeful ageing. Further, the availability and level of personalization reflects an 'ability' philosophy.

As indicated in Table 3 below, information pertaining to resident identity, wellness and ability is captured at different points in the care process (pre-admissions, admissions, daily care/real-time), using different tools and sensors.

Table 3: Resident information \& Sources

\begin{tabular}{|c|c|c|}
\hline $\begin{array}{l}\text { Wellness } \\
\text { Pillar }\end{array}$ & Type & Source \\
\hline \multirow[t]{7}{*}{ Bio-medical } & $\begin{array}{l}\text { Health profile, } \\
\text { ability, medications } \\
\text { and medical } \\
\text { directives }\end{array}$ & $\begin{array}{l}\text { Care Plan and } \\
\text { Assessments }\end{array}$ \\
\hline & $\begin{array}{l}\text { Diet and nutrition, } \\
\text { modified diet and } \\
\text { allergies }\end{array}$ & $\begin{array}{l}\text { Care Plan and } \\
\text { Assessments }\end{array}$ \\
\hline & $\begin{array}{l}\text { Current } \\
\text { Vitals/health status }\end{array}$ & $\begin{array}{l}\text { Nurse report, health } \\
\text { monitoring wearables }\end{array}$ \\
\hline & Daily care status & $\begin{array}{l}\text { Caregiver and nurse } \\
\text { reports } \\
\text { Sensor - care calls, } \\
\text { care visits }\end{array}$ \\
\hline & Medications status & Nurse report \\
\hline & $\begin{array}{l}\text { Current physical } \\
\text { activity }\end{array}$ & $\begin{array}{l}\text { Sensors - falls, bed } \\
\text { Self-reports } \\
\text { Caregiver and nurse } \\
\text { reports }\end{array}$ \\
\hline & $\begin{array}{l}\text { Current Frailty and } \\
\text { ADL }\end{array}$ & $\begin{array}{l}\text { Caregiver and nurse } \\
\text { reports } \\
\text { Sensors - activity, fall }\end{array}$ \\
\hline
\end{tabular}




\begin{tabular}{|c|c|c|}
\hline \multirow[t]{9}{*}{ Social } & $\begin{array}{l}\text { Communication } \\
\text { ability }\end{array}$ & $\begin{array}{l}\text { Care Plan and } \\
\text { Assessments }\end{array}$ \\
\hline & Daily Routine & $\begin{array}{l}\text { Personal Profile, Care } \\
\text { Plan }\end{array}$ \\
\hline & $\begin{array}{l}\text { Bio: personality and } \\
\text { preferences }\end{array}$ & Personal Profile \\
\hline & Family and friends & Personal Profile \\
\hline & $\begin{array}{l}\text { Interests and } \\
\text { Activities, Club } \\
\text { Memberships }\end{array}$ & Personal Profile \\
\hline & $\begin{array}{l}\text { Current social } \\
\text { activity - } \\
\text { events/clubs }\end{array}$ & $\begin{array}{l}\text { Events calendar } \\
\text { (attendance, level of, } \\
\text { change) }\end{array}$ \\
\hline & $\begin{array}{l}\text { Current family visits } \\
\text { (recent and } \\
\text { upcoming) }\end{array}$ & $\begin{array}{l}\text { Family visits log } \\
\text { Events calendar }\end{array}$ \\
\hline & $\begin{array}{l}\text { Current visits } \\
\text { outside }\end{array}$ & $\begin{array}{l}\text { Events calendar } \\
\text { Concierge requests } \\
\text { (taxi, bookings) }\end{array}$ \\
\hline & $\begin{array}{l}\text { Permissions } \\
\text { (information } \\
\text { sharing/access) }\end{array}$ & $\begin{array}{l}\text { Admissions } \\
\text { agreement }\end{array}$ \\
\hline \multirow[t]{3}{*}{ Psychological } & Mood & $\begin{array}{l}\text { Self-report } \\
\text { Report from } \\
\text { nurse/carer, family } \\
\text { Social activity (level } \\
\text { of, change) } \\
\text { Sensor - nurse calls, } \\
\text { activity }\end{array}$ \\
\hline & $\begin{array}{l}\text { Behaviour \& } \\
\text { challenging } \\
\text { behavior }\end{array}$ & $\begin{array}{l}\text { Report from nurse, } \\
\text { caregiver, family } \\
\text { Sensors - bed, activity } \\
\text { Care Plan and } \\
\text { Assessments (triggers } \\
\text { and soothers) }\end{array}$ \\
\hline & $\begin{array}{l}\text { Bio: who you are } \\
\text { and what matters, } \\
\text { important/meaningf } \\
\text { ul dates, } \\
\text { entertainment } \\
\text { preferences }\end{array}$ & Personal profile \\
\hline
\end{tabular}

\section{B. Community Concept \& Social Participation}

The objective is to foster and promote communication/connection between the resident and members of their community. The community concept is defined in relation to two structuring principles. Firstly, a distinction is drawn between an older person's personal community (i.e. family/friends) and their professional community (i.e. care team). A second distinction is made between the community inside the residential home and outside the residential home (i.e. family/friends and wider community).

The proposed technology supports different social interactions and roles (i.e. spouse, father, friend, care recipient, care assistant, nurse). Specifically, it empowers older people to have meaningful communications with relevant people in their personal and professional community.
The technology fosters communication/connection from the very beginning of the process. Prior to admissions, information is gathered about who the resident is and what matters to them. This 'profile' picture is advanced during the admissions process. At admissions, the system matches the resident with a buddy who has some common ground lifestyle, interests, personal history etc. The idea is that this buddy will help the older person navigate their new social and physical environment, setting expectations and providing reassurance. The system also recommends clubs to join and activities at the residential home which match the resident's interests. The resident can update this information at any time both during and after the admission process.

The resident can complete optional wellness surveys reporting on their sleep, pain, mood and so forth. Further, the system captures information about the resident's physical and social activity. Pending resident consent, this information can be shared with care staff and the resident's family. This information is helpful in relation to promoting meaningful communications between the resident, their care team and family members (i.e. the resident is not going to their usual activities, enjoyed a specific activity, not sleeping well, refusing food and so forth).

Moreover, the system enables social coaching - priming older people about relevant activities. This includes (1) general activities at the care home, (2) specific club activities (of which they are members), (3) family visits and/or communications (for example, photo sent by daughter, Skype call message), and (4) wider community events (including community volunteer projects or social events for older people supported by community volunteers).

\section{Design Solution}

Overall, the objective is to ensure simple and intuitive interactions. The design solution is adaptive in terms of agerelated changes and characteristics. Interactions are natural using touch. Currently, outputs are text/image based. Research is currently addressing multimodal aspects (i.e. voice synthesis and haptics). For an example of the graphical user interface, please see Figure 1 and 2 below.

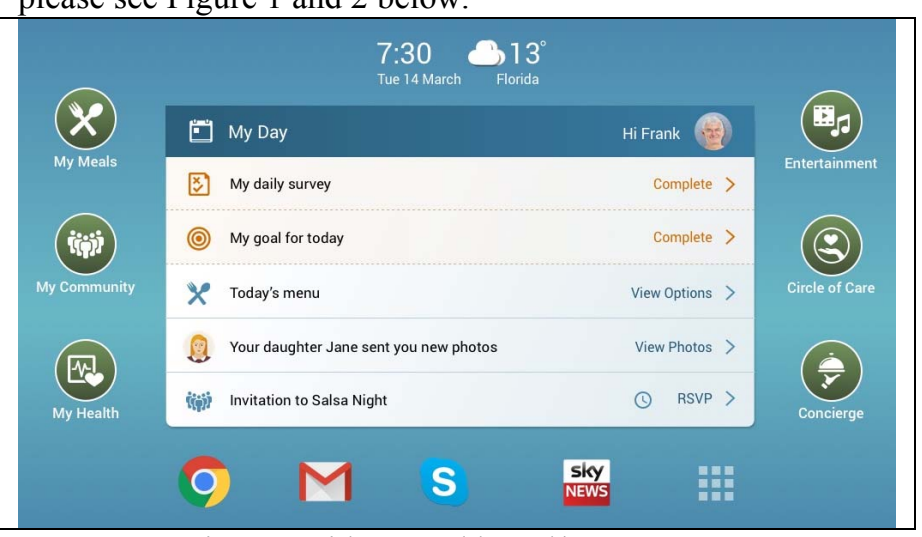

Fig 1: Resident Dashboard/Home Page 


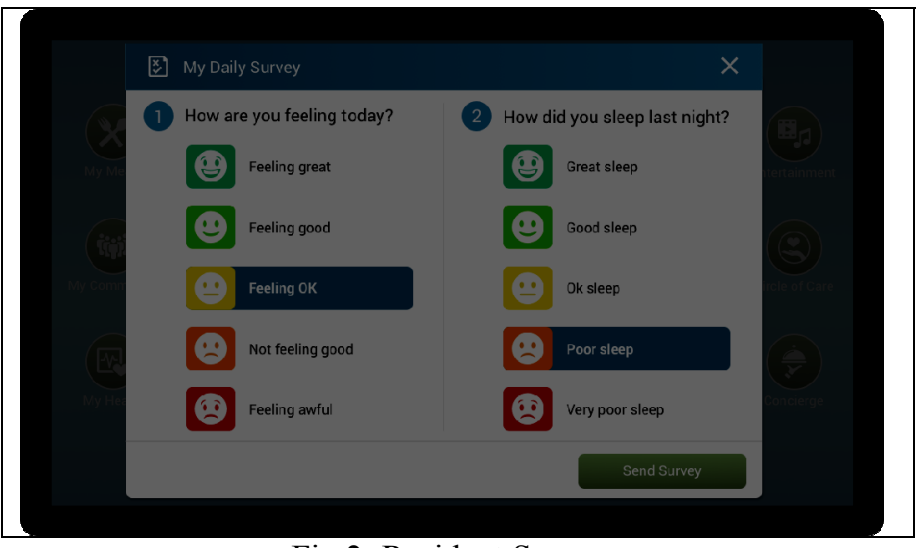

Fig 2: Resident Surveys

\section{DISCUSSION}

The advancement of assistive technology raises questions in relation to the meaning of care, and the role of people and technology in delivering care. The human dimensions and care implications of this technology must be carefully considered. Decision making regarding technology need and implementation must start from a principled basis - addressing resident states.

The proposed technology affords the opportunity to rethink care roles and how care is delivered. The system needs to coach all actors in relation to (1) providing care for older people, and (2) enabling social participation for older people. It is anticipated that the proposed technology will forge new roles and relationships between relevant stakeholders.

Well-being is strongly influenced by the quality of a older person's relationships with members of their personal and professional community. Relationship centered care provides the framework for thinking about care, the technology role and societal values. Future technology needs to consider both (1) the person and (2) enabling positive relationships and communications between seniors and relevant actors in their community. Specifically, the achievement of benefits in relation to resident experience, social participation, autonomy and well-being, is dependent on situating technology development in the context of enabling these relations.

\section{CONCLUSIONS}

The proposed technology enables an integrated society where older people (including those with Dementia and/or a disability) participate and engage in meaningful communications. Specifically, it enables a vision of care where older people are socially engaged (connected to community, have psychosocial occupation), and have continuity in living experience (i.e. concepts and living experience of home). Independence (and quality of life for older people) is linked to interdependence and fostering communication and social participation. Given models of relational autonomy and relationship centered care, technology is advanced for (1) older persons and (2) other relevant stakeholders in their social/health support network. Older people can benefit from coaching in relation to social participation and communication. Assistive technologies require careful consideration in relation to user acceptability, ease of use, adapting to age/condition, and issues around ethics. Residents should be able to opt in/out of all sensors. Technology should not be used to minimize and/or replace person centered care (including in person care). Further, it should enable the resident (i.e. independence) while considering the needs of care staff.

\section{REFERENCES}

[1] Silverstein, M., \& Parker, M. G. 2002. Leisure activities and quality of life among the oldest old in Sweden. Research on Aging, 24(5), 528547.

[2] Havelka M, Lucanin J, D. \& Lucanin D. 2009. Biopsychosocial model the integrated approach to health and disease. Coll Antropol. Mar;33(1):303-10

[3] Valtorta N and Hanratty B. 2012. Loneliness, isolation and the health of older adults: Do we need a research agenda? Journal of the Royal Society of Medicine, 105, 518-522

[4] Hillcoat-Nallétamby, S. 2014. The meaning of "independence" for older people in different residential settings. Journals of Gerontology, Series B: Psychological Sciences and Social Sciences, 69(3), 419-430.

[5] Barnes M, Blom A, Cox K. 2006. The social exclusion of older people: evidence from the first wave of the English Longitudinal Study of Ageing (ELSA): final Report. Office for the Deputy of Prime Minister.

[6] Soklaridis, S., Ravitz, P., Adler, G., Nevo, A., Lieff, S. 2016. Relationship-centered care in health: A 20-year scoping review, Patient Experience Journal, Volume 3, Issue 1 - Spring 2016, pp. 130-145

[7] Gawande, A. 2015. Being Mortal: Illness, medicine and what matters in the end. Profile Books, London

[8] Bødker, S., \& Burr, J. 2002. The Design Collaboratorium. A Place for Usability Design. ACM Transactions on Computer Human Interaction, 9(2), 152-169.

[9] Cousins, J. B., Whitmore, E., \& Shulha, L. 2013. Arguments for a Common Set of Principles for Collaborative Inquiry in Evaluation. American Journal of Evaluation, 34(1), 7-22.

[10] Smith, JA and Osborn, M. 2008. Interpretative phenomenological analysis. In JA Smith (Ed) Qualitative Psychology: A Practical Guide to Methods (second ed). London: Sage.

[11] Pruitt, J \& Jonathan Grudin. 2003. "Personas: Practice and Theory", Proceedings of the 2003 Conference on Designing for User Experiences (California, June, 2003). ACM, New York, USA.

[12] Wenger, E. 1998. Communities of practice: Learning, meaning, and identity. Cambridge: Cambridge University Press

[13] Cahill, J., McLoughlin, S., Wetherall S., Stolberg, M., \& O’Connor M. (2017). Addressing issues of need, adaptability, user acceptability and ethics in the participatory design of new technology enabling wellness, independence and dignity for seniors living in residential homes. Proceedings of the Third International Conference on Human Aspects of IT for the Aged Population (Part 11), ITAP 2017, held as part of HCI International 2017, Vancouver, BC, Canada, July 9-14, 2017, Springer 